\title{
Rituals and Data Analytics: A Mixed-Methods Model to Process Personal Beliefs
}

\author{
Daniel Burgos*
}

Research Institute for Innovation \& Technology in Education (UNIR iTED). Universidad Internacional de La Rioja (UNIR). 26006, Logroño, La Rioja (Spain)

Received 28 April 2021 | Accepted 20 June 2021 | Published 19 July 2021

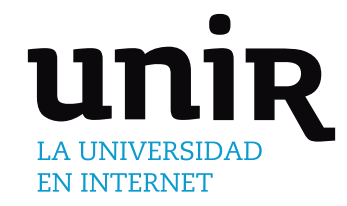

The goal of this research is to delve into ritual, religious, and secular phenomenology. It concentrates specifically on the relationship between pagan, cultural, celebratory, and traditional rituals and any other form of representation of a social sentiment focused on identifying, enjoying, or replacing a feeling (e.g. transcendence) as well as how these rituals overlap, replace, nourish, or make use of religious rituals bi-directionally. To achieve this goal, the research develops a semi-automatic process that leans on a mixed-methods approach, to explore the degree of ritual identity. This approach combines qualitative and quantitative research, applying a number of tools, such as systematic literature review, semi-structured interviews, data-analytics generic framework, and case studies. After a thorough systematic review of 251 publications, a semi-structured interview is designed and applied to 51 subjects. 10 significant aspects that define rituals are extracted. Subsequently, this list is completed with the 17 common elements of ritual identity from the systematic literature review. These combined indicators constitute the basis for building a data-analytics generic framework of ritual affinity through weighing each element's relevance and presence to obtain a degree of total affinity. That framework is then applied to 34 representative case studies. The core findings reinforce the initial hypothesis, determining that rituals follow a similar pattern of structure and preparation according to a predetermined set of common elements, whether linked to religious or secular settings.

Data Analytics, Mixedmethods, Pragmatism, Semi-automatic Process, Ritual.

\section{Research Foundation, Methodology, and Methods}

$\mathrm{T}$

HE hypothesis of this research states that there is a similarity

between religious and non-religious rituals regarding form, content, meaning, and, above all, structure. The study will seek to prove that rituals fulfil a given function, in a concrete context, with specific actors, and with a defined structure and that this entire frame or data-analytics generic framework is largely applicable to each ritual independently of creed, orientation, or social setting, whether religious, political, sports, family, or any other type' [1]-[2]. Further, the main research question is to determine if rituals follow a similar pattern of structure and preparation according to a predetermined set of common elements, whether linked to religious or secular settings; and if this pattern can be parameterised in a semi-automatic process through a data-analytics generic model.

The researcher used a hybrid methodology, which combines mixed methods under the pragmatic approach. Many disciplines prefer hybrid scientific research based on mixed methods [3]-[6]. Pragmatism combines knowledge-processing methods based on the research needs, the resource provision, and the researcher's view [7]-[8]. Pragmatism is widely used in social science research [9][10] and combines qualitative and quantitative methodologies [11].

* Corresponding author.

E-mail address: daniel.burgos@unir.net
The objectivist paradigm gives a thorough analysis from data series and user-tracking services, but it lacks the personal context to learn the unique reasons behind a decision or behaviour. In contrast, the constructivist paradigm offers a comprehensive picture of the subject's environment, but it lacks the large objective datasets to escalate and find user patterns. Pragmatism, however, uses both approaches, so the objective data complements subjective interpretation within context. Further, the research followed the pragmatic paradigm and a mixed-methods approach, combining action research with qualitative, experimental, and practical approaches [12]-[15].

The approach consists of four phases in a semi-automatic data analysis process [16]-[17]:

1. The observation phase will use anthropological patterns to collect data and identify patterns without intervention in the sample subjects or in the environment.

2. The interpretive phase will analyse the objective data with the aim of defining the behaviours, phases, and common elements found.

3. From that moment on, the methodology will be focused on a productive phase of design and production of a data-analytics generic framework that allows to group the patterns found.

4. Finally, the methodology will address a semi-experimental phase that will apply the design carried out in case studies, with the aim of validating the instrument and drawing conclusions from the application. 
For the interviews, the researcher used a qualitative approach for data categorisation and analysis since all the evidence was collected from personal, one-to-one, open discussions with experts. For the literature review, the researcher designed a systematic review strategy to look for the best-suited research papers, book chapters, books, and theses so that the selection fits the purpose of the study. For case studies, the researcher used a combined approach, qualitative for open questions to participants and quantitative in the way of a data-analytics generic framework with closed questions to the very same participants. In doing so, the research did benefit from a hybrid approach to the data analysis and interpretation of the findings.

\section{Systematic Literature Review}

A systematic review is defined as a process for identifying literature according to search and inclusion criteria in a specific field of study [18]. Such a review is scientific research per se with the clear objective of determining the state of the art for a field of study as a result of analysing work done by third parties [19]-[20].

\section{A. Databases Used}

The reference search has been executed on the Web of Science (WoS) platform, maintained by the multinational Thomson Reuters and comprising 12,000 important magazines, including Open Access, and over 160,000 conference minutes. WoS comprises over 800 million references and constitutes the largest database of academic and scientific articles focused on the social sciences, science, and humanities. IBCSR Research Review, APA PsycINFO, APA PsycBOOKS, APA PsycARTICLES, the Wiley-Online Library, Sociological Abstracts, Dialnet, Academic Search Premiere EBSCO, SAGE Premier, Scopus, and Taylor \& Francis were also used. They were accessed from the Bodleian Library at Oxford University, Westminster University in London, the Gregorian University in Rome, the University of Barcelona, and the Universidad Internacional de La Rioja (UNIR) in Logroño. Google Scholar was also used principally for published books and un-indexed complementary studies (generally not included in the aforementioned databases).

\section{B. Steps Carried Out in the Systematic Review}

The systematic review followed the flow and steps presented in Fig. 1.

After discarding 69 references ( 8 doctoral theses, 45 articles, and 16 books), the final selection for the study constituted 9 doctoral theses, 196 articles, and 46 books, totalling 251 references deserving a calibrated in-depth study within the research process (Fig. 2).

\begin{tabular}{|c|c|c|c|c|c|c|c|}
\hline $\begin{array}{c}\text { Selection } \\
\text { Stages }\end{array}$ & $\begin{array}{c}\text { References } \\
\text { identifies in } \\
\text { electronic } \\
\text { databases } \\
\text { according } \\
\text { to search } \\
\text { terms }\end{array}$ & $\begin{array}{c}\text { Excluded. } \\
\text { Non- } \\
\text { relevant } \\
\text { studies by } \\
\text { title and } \\
\text { summary }\end{array}$ & $\begin{array}{c}\text { Relevant } \\
\text { references } \\
\text { by Title } \\
\text { and } \\
\text { summary }\end{array}$ & $\begin{array}{c}\text { Excluded. } \\
\text { Body not } \\
\text { related to } \\
\text { research }\end{array}$ & $\begin{array}{c}\text { Relevant } \\
\text { references } \\
\text { by body }\end{array}$ & $\begin{array}{c}\text { Excluded. } \\
\text { Non-relevant } \\
\text { contribution } \\
\text { to research } \\
\text { for failing to } \\
\text { meet } \\
\text { inclusion } \\
\text { criteria }\end{array}$ & $\begin{array}{c}\text { References that } \\
\text { meet all the } \\
\text { selection } \\
\text { criteria and } \\
\text { whose in-depth } \\
\text { analysis } \\
\text { ans } \\
\text { for the revancearch }\end{array}$ \\
\hline Thesis & 36 & 12 & 24 & 7 & 17 & 8 & 9 \\
\hline Papers & 442 & 114 & 328 & 87 & 241 & 45 & 196 \\
\hline Books & 107 & 21 & 86 & 24 & 62 & 15 & 46 \\
\hline N & $\mathbf{5 8 5}$ & $\mathbf{1 4 7}$ & $\mathbf{4 3 8}$ & $\mathbf{1 1 8}$ & $\mathbf{3 2 0}$ & $\mathbf{6 9}$ & $\mathbf{2 5 1}$ \\
\hline
\end{tabular}

Fig. 2. References selected by publication type at each stage.

\section{Findings from the Systematic Review}

The main aspects that define rituals extracted from the systematic literature review are 17 common elements of ritual identity: (1) transcendence, (2) feeling, (3) meaning, (4) transformation, (5) contextualisation, (6) polysemy, (7) music, (8) need, (9) representation of reality, (10) ceremony, (11) stages, (12) formality, (13) script, (14) impact, (15) invariability, (16) periodicity, and (17) symbolism [21][30]. Following and based on these findings, an interview protocol and questionnaire were designed.

\section{INTERVIEW DESIGN}

\section{A. Description of the Target Group and the Sample}

The study targeted university graduates with work experience and sensitivity towards the subject matter but without a background in philosophy, anthropology, or theology or specific knowledge of the terminology. The intention was that they should answer freely and be interested in staying updated on the process and the results. The interviews were conducted mainly in Spanish, English, and French. Furthermore, a script has been prepared in Italian and Portuguese; these scripts can be used as a base to further explain some concepts but not for primary-language interviews.

Within these parameters, the researcher required responsible, cultured adults, sensitive to the subject matter, who could provide first-hand information with personal interpretations of religious, sports, political, musical, family, intimate, or any other type of ritual previously described. The intention was to gather information from people who had not been influenced by prior studies or texts

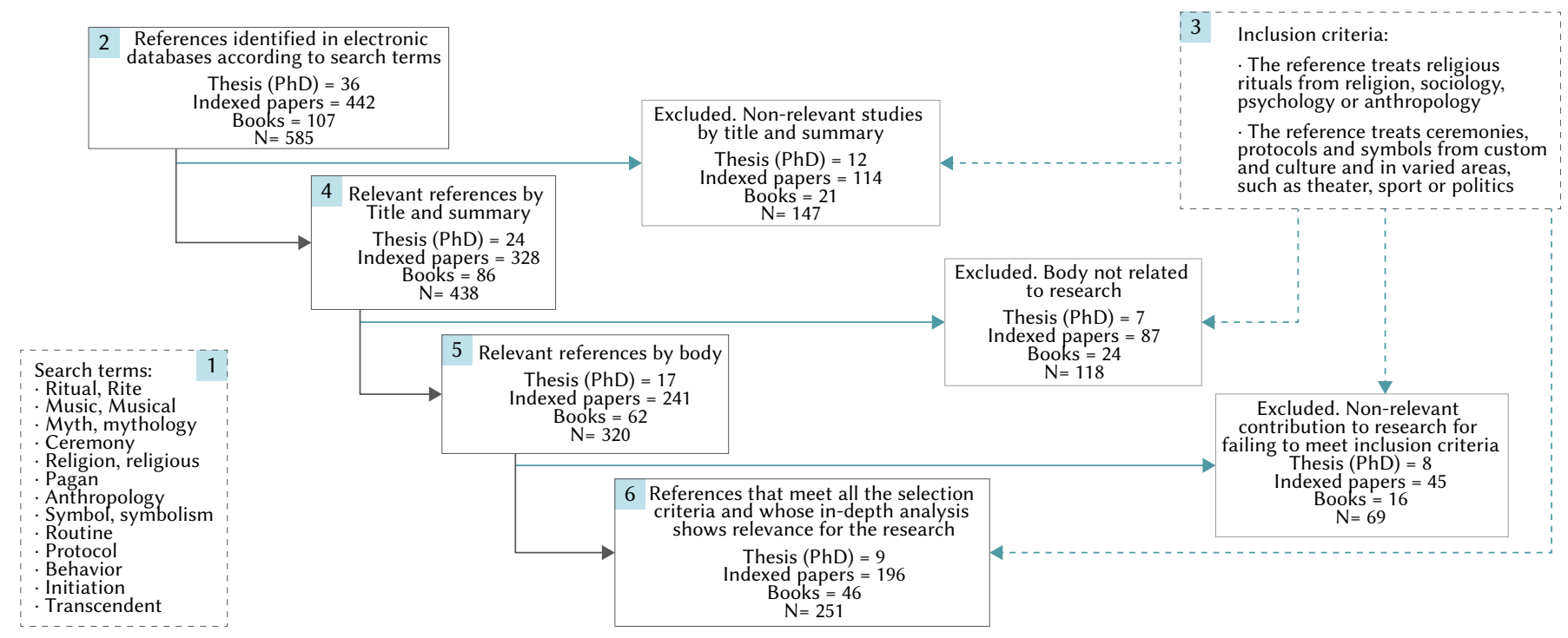

Fig. 1. Steps in the reference selection process and results by type of publication. 
developed on this matter so that they could express themselves while free of either active or passive guidance. In a sense, the researcher sought a popular and educated voice given the mundane and popular aspect inherent to rituals.

The sample consists of 51 interviewees, of which 20 are women and 31 are men; 23 reside in Spain, and 28 are distributed among Saudi Arabia, Argentina, Australia, Belgium, Brazil, Chile, Colombia, Ecuador, England, Morocco, Mexico, New Zealand, the United Kingdom, the Dominican Republic, and Venezuela. Ages range from 24 to 73 years. All are graduates. Furthermore, 21 are practicing Catholics, 2 are Muslims, 2 are Protestants, 21 are not worshippers or are atheists, and 5 declined to answer. Lastly, 30 Catholic, 2 Protestant, 2 Muslim, 1 Jewish, 2 popular belief, 3 therapeutic, 4 intimate, 9 spiritual, 8 sporting, 2 artistic, and 6 social rituals have been described (occasional double classification).

The interview phase was conducted from September 2017 to July 2018 and took place in the cities of Sao Paulo (Brazil), Marrakech (Morocco), Brussels (Belgium), Quito (Ecuador), Paris (France), Toronto (Canada), Buenos Aires (Argentina), Bogotá (Colombia), Jeddah (Saudi Arabia), and Santa Cruz de Tenerife, Salamanca, Madrid, Murcia, León, and Logroño (Spain).

\section{B. Design and Description of the Base Script}

The interview script has been structured in eight sections or categories. Each section is composed of several questions, with at least one considered as primary (that is, requiring an answer). In this manner, the core of the primary questions constitutes the basic outline with which the interview must be conducted; the remaining questions are thus complementary. There is a total of 9 categories, 74 possible questions, and 18 primary questions (including the informed consent), together with 3 fixed pieces of information (unique identifier, date, and time).

The questions can be open (free development) or closed (restricted answers). There are 4 mixed (predetermined answers with the option of additional freely developed comments) and 3 fixed data fields. The final script template has been centralised in an online database to be able to feed and analyse it instantly and coherently from different geographic locations. Centralised dumping has proven to be a very valuable tool for the in-depth comparison and coherent cross-analysis of the interviews. Given the interest generated by the research, the centralised database includes an online form to be used in a subsequent research phase.

The categories taken into account are as follows: sample, scope, characterisation, meaning, behaviour, transference, evolution, and impact. The questions and type of associated question in each category are attached as Appendix I.

The semi-structured interview included 62 questions, 18 of which were primary or mandatory, and was divided into 8 sections and conducted with 51 individuals. The questions were categorised as sample, scope, characterisation, meaning, behaviour, transference, evolution, or impact questions.

The interview subjects were university graduates with work experience in and sensitivity towards the subject matter. The researcher preferred to interview people who had not studied subjects related to rituals, such as philosophy, anthropology, or theology. The interviews were conducted mainly in Spanish, English, and French, and the script was also prepared in Italian and Portuguese to be used occasionally as support. The researcher thus hoped to find responsible, cultured interview subjects who were sensitive to the research subject and who could voice their opinions and interpret them without being influenced by formal education. In short, the researcher sought the voice of the informed person to learn the mundane and popular aspects inherent in rituals.

\section{Findings from the Interview Phase}

The analysis of the 51 interviews evidenced a recurring number of 10 primary aspects:

1. The participants exhibited a high degree of affinity towards the ritual as well as a transcendence of the event beyond the daily custom.

2. The ritual overlapped with the introspection ceremony - a large number of interviewees had periodically explored an act of synchronisation between the individual and their surroundings.

3. The participants often confused terminology, some of which was basic and general knowledge, and had overlapping beliefs and definitions. The researcher perceived that the starting concepts were fuelled by creative definitions.

4. The participants were unfamiliar with the depth of religious, choral, and/or social rituals. The roles, characteristics, or symbols, for example, were familiar yet not known in detail.

5. The participants exhibited a need to express and move beyond the mundane to experience a transcendent feeling, whether personal or collective.

6. The sample was clearly and universally cross-sectional or transversal regardless of culture, religion, or type of ritual, with a marked range of ages, languages, and backgrounds. Nevertheless, the researcher found similar or identical answers and attitudes across the entire group and often had the impression of hearing the same person talk through different mouths.

7. Each participant interpreted a ritual differently, granting it singularity and a specific meaning (i.e. polysemy). Thus, while maintaining structure, steps, or symbols, each individual or collective ritual acquired personality through the eyes and actions of each participant.

8. The widespread use of vocal or instrumental music was a recurrent pattern. The ritual was the same with or without music, but the music - whether it was chanting, a song, background, a cappella, with instruments, or with harmony - represented a catalyst for the individual's or the group's participation.

9. The ritual was essential and indispensable for all the interview subjects. Human beings need to express themselves and articulate expression through a ritual.

10. The participants experienced evocation through rituals, awakening memories, feelings, and moods.

These findings will help in modelling the data-analytics generic framework, as shown in the following sections.

\section{Data-Analytics Generic Framework for Rituals}

This section establishes a data-analytics generic framework for standardising the structure, processes, and behaviours of rituals. The final intent is to design the most abstract model possible that is able, most precisely, to identify a wide range of rituals according to category, orientation, intent, population, and other criteria.

The data-analytics generic framework seeks to set parameters for measuring the ritual identity of an event or celebration. This framework, therefore, will analyse this hypothesis based on identity, composition, context, and other factors of any type of celebration, whether religious or secular. To that end, the framework is constructed by parameterising and weighting the common elements that allow for a generic approach and, therefore, are normally applicable to any event or celebration. 


\section{A. Identifying the Elements that Characterise a Ritual}

From all the material studied for this section, the researcher highlights [22], [25], [31]. They all note the systemisation of the components and sections of a ritual from different points of view.

Four steps were taken to identify the common characteristics; the first step was to select up to 10 key aspects identified during the interviews (Table I).

TABLE I. Key Aspects From InTERVIEwS

\begin{tabular}{|c|c|}
\hline Aspect \# & Description of key aspect \\
\hline 1 & Transcendence and affinity with the ritual moment \\
\hline 2 & Overlapping among ritual, introspection, expression, and feeling \\
\hline 3 & Unclear definition of terms \\
\hline 4 & Unfamiliarity with rituals \\
\hline 5 & Need for expression \\
\hline 6 & Transverse approach \\
\hline 7 & Polysemy \\
\hline 8 & Music \\
\hline 9 & Indispensability \\
\hline 10 & Evocation \\
\hline
\end{tabular}

In the second step, the researcher selected and combined common elements found in the literature review. Each element listed below includes a brief description and at least one reference of renowned authors who used them in their work (Table II):

TABLE II. COMMON ELEMENTS From the Literature ANALysis

\begin{tabular}{|c|c|c|}
\hline Element & Explanation & Supporting reference 1 \\
\hline Ceremony & $\begin{array}{c}\text { Expressed through } \\
\text { representation or an act }\end{array}$ & $\begin{array}{l}\text { Bell, } 1997 \text { [2]; Van } \\
\text { Gennep, } 2011 \text { [29] }\end{array}$ \\
\hline Contextualisation & $\begin{array}{c}\text { Makes sense in a specific } \\
\text { context }\end{array}$ & $\begin{array}{l}\text { McCauley \& Lawson, } \\
1999 \text { [26] }\end{array}$ \\
\hline Stages & Stages are clearly defined & Kelly \& Kaplan, 1990 [31] \\
\hline Formality & Performed in a formal setting & Bell, 1997 [2] \\
\hline Script & $\begin{array}{l}\text { Designed according to a } \\
\text { script with roles and sections }\end{array}$ & $\begin{array}{c}\text { McCauley \& Lawson, } \\
\text { 1999, } 2002 \text { [32]; Staal, } \\
1979 \text { [33] }\end{array}$ \\
\hline Impact & $\begin{array}{c}\text { Produces an impact on the } \\
\text { subject }\end{array}$ & $\begin{array}{l}\text { Eliade, } 1957[24] ; \\
\text { Turner, } 1967[28]\end{array}$ \\
\hline Invariability & $\begin{array}{l}\text { Repeated over time without } \\
\text { major alterations }\end{array}$ & $\begin{array}{c}\text { Staal, } 1979[33] \text {; Bell, } \\
1997[2]\end{array}$ \\
\hline Music & $\begin{array}{l}\text { Music used in a significant } \\
\text { way }\end{array}$ & Grimes, 2014 [25] \\
\hline Need & $\begin{array}{c}\text { The ritual is required } \\
\text { to guarantee stability, } \\
\text { commitment, meaning, or } \\
\text { any other aspect }\end{array}$ & $\begin{array}{l}\text { Fredericks, } 2021[34] ; \\
\text { Freston, } 2001[35]\end{array}$ \\
\hline Regularity & Repeated periodically & Bell, 1997 [2] \\
\hline Polysemy & $\begin{array}{l}\text { Interpreted differently } \\
\text { depending on who and how }\end{array}$ & $\begin{array}{l}\text { Turner, } 1967[28] ; \\
\text { Eliade, } 1957[24]\end{array}$ \\
\hline $\begin{array}{l}\text { Representation } \\
\text { of reality }\end{array}$ & $\begin{array}{l}\text { Performed to evoke or } \\
\text { represent reality }\end{array}$ & Eliade, 1957 [24] \\
\hline Feeling & Arouses genuine feeling & Driver, 2006 [23] \\
\hline Meaning & Involves expressing meaning & $\begin{array}{c}\text { Leach, } 1966[36] ; \\
\text { Durkheim \& Swain, } \\
2008[37]\end{array}$ \\
\hline Symbolism & $\begin{array}{l}\text { Uses symbols linked to } \\
\text { feelings or meanings }\end{array}$ & Bell, 1997 [2] \\
\hline Transcendence & Elevates the spirit & $\begin{array}{l}\text { Grimes, } 2014 \text { [25]; } \\
\text { Strenski, } 1991 \text { [38] }\end{array}$ \\
\hline Transformation & $\begin{array}{c}\text { Causes a change of state or } \\
\text { status }\end{array}$ & $\begin{array}{l}\text { Driver, } 2006[23] ; \\
\text { Grimes, } 2014[25]\end{array}$ \\
\hline
\end{tabular}

The third step matched the aspects identified during fieldwork (\#1-10) with elements extracted from the analysis of the systematic literature review to find comparable meanings (Table III):

TABLE III. PAiring of Aspects from Interviews AND Elements in the LITERATURE

\begin{tabular}{|c|c|c|c|}
\hline Elements & Explanation & $\begin{array}{c}\text { Key } \\
\text { aspect }\end{array}$ & $\begin{array}{l}\text { Description of } \\
\text { key aspect }\end{array}$ \\
\hline Ceremony & $\begin{array}{l}\text { Expressed through } \\
\text { representation or } \\
\text { an act }\end{array}$ & & \\
\hline Contextualisation & $\begin{array}{l}\text { Makes sense in a } \\
\text { specific context }\end{array}$ & \#6 & Transverse approach \\
\hline Stages & $\begin{array}{c}\text { Stages are clearly } \\
\text { defined }\end{array}$ & & \\
\hline Formality & $\begin{array}{c}\text { Performed in a formal } \\
\text { setting }\end{array}$ & & \\
\hline Script & $\begin{array}{c}\text { Designed according to } \\
\text { a script with roles and } \\
\text { sections }\end{array}$ & & \\
\hline Impact & $\begin{array}{c}\text { Produces an impact on } \\
\text { the subject }\end{array}$ & & \\
\hline Invariability & $\begin{array}{c}\text { Repeated over time } \\
\text { without major } \\
\text { alterations }\end{array}$ & & \\
\hline Music & $\begin{array}{l}\text { Music used in a } \\
\text { significant way }\end{array}$ & $\# 8$ & Music \\
\hline Need & $\begin{array}{l}\text { The ritual is required } \\
\text { to guarantee stability, } \\
\text { commitment, } \\
\text { meaning, or any other } \\
\text { aspect }\end{array}$ & \#9 & Indispensability \\
\hline Regularity & Repeated periodically & & \\
\hline Polysemy & $\begin{array}{c}\text { Interpreted differently } \\
\text { depending on who } \\
\text { and how }\end{array}$ & \#7 & Polysemy \\
\hline $\begin{array}{l}\text { Representation of } \\
\text { reality }\end{array}$ & $\begin{array}{l}\text { Performed to evoke or } \\
\text { represent reality }\end{array}$ & \#10 & Evocation \\
\hline Feeling & $\begin{array}{l}\text { Arouses genuine } \\
\text { feeling }\end{array}$ & $\# 2$ & $\begin{array}{l}\text { Overlapping among } \\
\text { ritual, introspection, } \\
\text { expression, and } \\
\text { feeling }\end{array}$ \\
\hline Meaning & $\begin{array}{l}\text { Involves expressing } \\
\text { meaning }\end{array}$ & $\# 5$ & $\begin{array}{l}\text { Need for expression, } \\
\text { for experiencing } \\
\text { something beyond } \\
\text { the day-to-day }\end{array}$ \\
\hline Symbolism & $\begin{array}{c}\text { Uses symbols } \\
\text { linked to feelings or } \\
\text { meanings }\end{array}$ & & \\
\hline Transcendence & Elevates the spirit & $\# 1$ & $\begin{array}{l}\text { Transcendence and } \\
\text { affinity with the } \\
\text { ritual moment }\end{array}$ \\
\hline Transformation & $\begin{array}{c}\text { Causes a change of } \\
\text { state or status }\end{array}$ & $\# 5$ & $\begin{array}{l}\text { Need for expression, } \\
\text { for experiencing } \\
\text { something beyond } \\
\text { the day-to-day }\end{array}$ \\
\hline
\end{tabular}

During this pairing process, the researcher found that two key aspects are not reflected in the systematic review (Table IV):

TABLE IV. Discarded Aspects From Interviews

\begin{tabular}{|c|c|}
\hline Aspect \# & Description of key aspect \\
\hline 3 & Unclear definition of terms and concepts \\
\hline 4 & In-depth unfamiliarity with religious rituals \\
\hline
\end{tabular}


The researcher also identified Aspect \#5 (need for expression) with two elements from the literature: meaning and transformation, all focused on causing a change in state or status and on the need for expression, for experiencing something beyond the mundane. Thus, the researcher identified 8 out of the 10 aspects from the fieldwork analysis as key elements in the definition and identification of a ritual according to the group of authors and work analysed in the systematic literature review. The researcher found that Aspects \#3 and \#4 correspond with the interpretation of the sample and with the understanding of the process and ritual identity. They cannot, therefore, be considered as definitions of the ritual itself but of a characteristic of the population sample. Though interesting as a feature of context and sample, they are not relevant to the definition of a generic framework that identifies key aspects of the research subject. Therefore, the researcher did not include them in the final list of the framework elements.

In the fourth and last step, the researcher organised the list of elements, prioritising the ones found during fieldwork. It should be noted that this prioritisation merely follows grouping and aesthetic criteria and does not include any special assignment or identification within the framework (Table V).

This table represents the list of elements that characterise a ritual, resulting from combining the findings of the analysis of the systematic review of literature and those of the fieldwork, which was carried out as semi-structured qualitative interviews.

\section{B. Informing the Data-analytics Generic Framework}

Having selected and prioritised the elements that make up the dataanalytics generic framework, the researcher established a weighting system that permits the calibration of each element's importance according to the individual and the event or celebration [39]. Two values should be considered: (1) the value that the individual assigns to an element based on how much they believe it to be present in the ritual being evaluated; and (2) the absolute weight of importance that the element has in the ritual being evaluated. In other words, what presence does a specific element have, and what is the relevance of that presence within the entirety of the ritual's definition?

To standardise the weights, the researcher chose the Likert scale [40]-[41], which measures from 'highly against' to 'highly in favour', on a scale from 1 to 5: (1) 'strongly disagree', (2) 'disagree', (3) 'neutral', (4) 'agree', and (5) 'strongly agree'. The researcher chose to include a sixth degree, '(0) completely disagree', which takes into consideration frontal opposition since (1) 'strongly disagree' may still indicate a positive score, even if there is none. This way, and by adapting the scale to the framework, each element is valued by a set of degrees ranging from 0 to 5 (from 'non-existent' to 'maximum') - on one hand, the relevance of the element according to the subject's perspective and, on the other hand, the level of its presence in the ritual being evaluated.

It is necessary to highlight the importance of this double weighting, which is designed to offer a unique calibrating system that works irrespective of whether the evaluator is an individual actively participating in the ritual or an external observer (e.g. as researcher). In the first case, the context of a ritual and the individual's interpretation regarding the relevance of its different elements are still significant in the experience, impact, and transcendence of the ritual [42]-[44]. In this sense, the individual is not merely a consumer or a spectator but rather a vehicle of celebration of the ritual experience. The individual becomes a conduit of the expression, interpretation, and meaning of the ritual. In summary, they are a part of the scene's assessment and are jointly or uniquely responsible for the final representation, thus combining both active roles. Therefore, the individual must evaluate both aspects (degree of relevance and degree of presence) to provide a unique and personal assessment of the identity of the event or
TABLE V. Matching AND Grouping of the Elements

\begin{tabular}{|c|c|c|c|c|}
\hline$\#$ & Elements & Explanation & $\begin{array}{c}\text { Key } \\
\text { aspect }\end{array}$ & $\begin{array}{c}\text { Description of } \\
\text { key aspect }\end{array}$ \\
\hline 1 & Transcendence & Elevates the spirit & $\# 1$ & $\begin{array}{c}\text { Transcendence and } \\
\text { affinity with the ritual } \\
\text { moment }\end{array}$ \\
\hline 2 & Feeling & $\begin{array}{l}\text { Arouses genuine } \\
\text { feeling }\end{array}$ & $\# 2$ & $\begin{array}{l}\text { Overlapping among } \\
\text { ritual, introspection, } \\
\text { expression, and feeling }\end{array}$ \\
\hline 3 & Meaning & $\begin{array}{c}\text { Involves expressing } \\
\text { meaning }\end{array}$ & $\# 5$ & $\begin{array}{c}\text { Need for expression, for } \\
\text { experiencing something } \\
\text { beyond the mundane }\end{array}$ \\
\hline 4 & Transformation & $\begin{array}{c}\text { Causes a change of } \\
\text { state or status }\end{array}$ & $\# 5$ & $\begin{array}{l}\text { Need for expression, for } \\
\text { experiencing something } \\
\text { beyond the mundane }\end{array}$ \\
\hline 5 & Contextualisation & $\begin{array}{l}\text { Makes sense in a } \\
\text { specific context }\end{array}$ & \#6 & Transverse approach \\
\hline 6 & Polysemy & $\begin{array}{c}\text { Interpreted } \\
\text { differently } \\
\text { depending on who } \\
\text { and how }\end{array}$ & \#7 & Polysemy \\
\hline 7 & Music & $\begin{array}{l}\text { Music used in a } \\
\text { significant way }\end{array}$ & $\# 8$ & Music \\
\hline 8 & Need & $\begin{array}{l}\text { The ritual is } \\
\text { required to } \\
\text { guarantee stability, } \\
\text { commitment, } \\
\text { meaning, or any } \\
\text { other aspect }\end{array}$ & $\# 9$ & Indispensability \\
\hline 9 & $\begin{array}{c}\text { Representation of } \\
\text { reality }\end{array}$ & $\begin{array}{l}\text { Performed to evoke } \\
\text { or represent reality }\end{array}$ & $\# 10$ & Evocation \\
\hline 10 & Ceremony & $\begin{array}{l}\text { Expressed through } \\
\text { representation or } \\
\text { an act } \\
\end{array}$ & & \\
\hline 11 & Stages & $\begin{array}{c}\text { Stages are clearly } \\
\text { defined }\end{array}$ & & \\
\hline 12 & Formality & $\begin{array}{l}\text { Performed in a } \\
\text { formal setting }\end{array}$ & & \\
\hline 13 & Script & $\begin{array}{l}\text { Designed according } \\
\text { to a script with } \\
\text { roles and sections }\end{array}$ & & \\
\hline 14 & Impact & $\begin{array}{c}\text { Produces an impact } \\
\text { on the subject }\end{array}$ & & \\
\hline 15 & Invariability & $\begin{array}{c}\text { Repeated over time } \\
\text { without major } \\
\text { alterations }\end{array}$ & & \\
\hline 16 & Regularity & $\begin{array}{c}\text { Repeated } \\
\text { periodically }\end{array}$ & & \\
\hline 17 & Symbolism & $\begin{array}{l}\text { Uses symbols } \\
\text { linked to feelings } \\
\text { or meanings } \\
\end{array}$ & & \\
\hline
\end{tabular}

celebration with the archetypical ritual defined by the elements of the generic framework.

In the second case, where the evaluator of the ritual is external (e.g. a researcher) and not an active participant, the double calibration system allows them to measure the relative weight of each element according to the context, including the subject of the assessment [45][46]. In this way, the experience is customised through a personal application of the general parameters according to each evaluator's gauge. In both cases, active participant and external observer, the system offers greater accuracy in terms of matching the event or celebration with the general ritual framework given the common elements that define them. 
Thus, affinity is ruled by two combined values on a Likert scale of 0 ('non-existent') to 5 ('maximum'), which was multiplied to obtain one value. Given that multiplication ranges between 0 ('non-existent') and 25 ('maximum'), for easier understanding, it was changed into a percentage scale from $0 \%(=0$, non-existent $)$ to $100 \%(=25$, maximum $)$. Each element provides a percentage value. The total affinity of the event or celebration with the general ritual framework is the proportion of the percentage values of the 17 elements $(n=17)$ over the maximum possible value. The following equation shows the total affinity as a percentage value, resulting from calculating over the set of elements assessed in relevance and presence:

$$
\operatorname{Affinity}(n)=\frac{\sum_{i=1}^{n}(\operatorname{Relevance}(i) * \operatorname{Presence}(i))}{\sum_{i=1}^{n}(\operatorname{Relevance}(i) * \operatorname{Max}(0: 5))}
$$

For ease of interpretation, (a) decimals were limited, and (b) colours to sections were assigned, as follows (Table VI):

TABLE VI. Affinity by SEction And RANge

\begin{tabular}{|c|c|c|c|}
\hline Section & $\begin{array}{c}\text { Affinity range (absolute } \\
\text { value: ABS) }\end{array}$ & $\begin{array}{c}\text { Affinity range } \\
\text { (relative value: } \%)\end{array}$ & Interpretation \\
\hline 1 & $0.00-6.00$ & $0 \%-24 \%$ & Minimum \\
\hline 2 & $6.25-12.25$ & $25 \%-49 \%$ & Low \\
\hline 3 & $12.50-18.50$ & $50 \%-74 \%$ & High \\
\hline 4 & $18.75-24.00$ & $75 \%-100 \%$ & Maximum \\
\hline
\end{tabular}

The final dashboard of the data-analytics generic framework is shown in Fig. 3.

\section{Selection of Case Studies}

Rituals already assimilated by the various communities of practice do not represent a validation challenge. A Catholic sacrament, the daily prayer cycle of Islam, the chanting of Buddhist mantras, or the offering of Taoist incense are rituals established in their creeds, incorporated by their communities, and used by their practitioners. It is not the subject of this thesis to question established rituals but, as indicated by Research Question 2, to delve into the similarities between religious and secular rituals: 'Do religious and secular rituals maintain an equal or similar structure at different times or contexts of application?' In other words, are secular rituals comparable to religious ones in their identity as rituals in that they both maintain a comparable structure and definition? To this end, a selection of secular and religious rituals was made as case studies to which researcher applied the generic framework. These can be personal or group rituals, more or less community based, and more or less mundane or general. They meet the condition that they have been published at some point and are therefore open to reference; for each case, a list of references that define it in detail is attached.

The goal of applying the framework is not to catalogue or describe each case in detail but to draw conclusions from the application of the tool to the potential ritual to analyse the degree of affinity it shows

\begin{tabular}{|c|l|l|}
\hline Caso-ID & Title & Initiation into a Salvadoran gang ("mara") \\
\hline $\mathbf{0 4}$ & References & Hume, 2007; Miguel Cruz, 2010 \\
\hline \multirow{2}{*}{ Stages } & $\begin{array}{l}\text { Candidacy, proof, personal detachment, group assumption, tatoo membership, } \\
\text { submission to leader }\end{array}$ \\
\cline { 2 - 3 } & Roles (who) & Initiator, applicant, group \\
\hline \multirow{2}{*}{ Justification (why) } & $\begin{array}{l}\text { The feeling of belonging to a group and submission to a leader leads to joining in } \\
\text { an act that requires showing value and loss of self-identity to assume the group }\end{array}$ \\
\hline Moment (when) & Just one time \\
\hline Meaning (what) & Assumption of group identity and submission to a leader \\
\cline { 2 - 3 } & Type & Initiation \\
\hline & Context & Group \\
\hline
\end{tabular}

\section{Description}

A candidate (young, usually) wants to join a criminal group, closed and structured. To do this, you must go through an identity and loyalty process with that group and with your boss. Only if you pass the input tests and the steps of the final event will you be admitted as a brotherhood or sibling within the group

\begin{tabular}{|c|c|c|c|c|c|}
\hline $\begin{array}{c}\text { Element } \\
\text { ID }\end{array}$ & Element of the ritual & Relevance & Presence & $\begin{array}{c}\text { Affinity } \\
(\mathbf{A B S})\end{array}$ & $\begin{array}{c}\text { Affinity } \\
(\mathbf{\%})\end{array}$ \\
\hline & \multicolumn{2}{|c|}{} & & $239 / 330$ & $\mathbf{7 2 \%}$ \\
\hline $\mathbf{1}$ & Transcendence & 5 & 3 & 15 & $0 \%$ \\
\hline $\mathbf{2}$ & Feeling & 5 & 5 & 25 & $100 \%$ \\
\hline $\mathbf{3}$ & Meaning & 5 & 4 & 20 & $80 \%$ \\
\hline $\mathbf{4}$ & Transformation & 5 & 5 & 20 & $80 \%$ \\
\hline $\mathbf{5}$ & Contextualization & 4 & 0 & 0 & $0 \%$ \\
\hline $\mathbf{6}$ & Polysemy & 1 & 4 & 20 & $80 \%$ \\
\hline $\mathbf{7}$ & Music & 5 & 3 & 15 & $60 \%$ \\
\hline $\mathbf{8}$ & Need & 5 & 0 & 0 & $0 \%$ \\
\hline $\mathbf{9}$ & Representation of reality & 4 & 5 & 20 & $80 \%$ \\
\hline $\mathbf{1 0}$ & Ceremony & 3 & 5 & 15 & $60 \%$ \\
\hline $\mathbf{1 1}$ & Stages & 3 & 5 & 15 & $60 \%$ \\
\hline $\mathbf{1 2}$ & Formality & 5 & 5 & 25 & $100 \%$ \\
\hline $\mathbf{1 3}$ & Script & 2 & 5 & 10 & $40 \%$ \\
\hline $\mathbf{1 4}$ & Impact & 3 & 5 & 15 & $60 \%$ \\
\hline $\mathbf{1 5}$ & Invariability & 2 & 2 & 4 & $16 \%$ \\
\hline $\mathbf{1 6}$ & Regularity & 5 & 20 & $80 \%$ \\
\hline $\mathbf{1 7}$ & Symbolism & & & \\
\hline
\end{tabular}

\begin{tabular}{|c|c|c|}
\hline $\begin{array}{c}\text { Nr. of elements } \\
\text { per range }\end{array}$ & $\begin{array}{c}\text { Affinity range } \\
\text { (absolute value) }\end{array}$ & $\begin{array}{c}\text { Affinity range } \\
\text { (relative: } \%)\end{array}$ \\
\hline $\mathbf{1 7}$ & $\mathbf{2 3 9}$ & $\mathbf{1 0 0 \%}$ \\
\hline Minimum (4) & 4,00 & $1,67 \%$ \\
\hline Low (1) & 10,00 & $4,18 \%$ \\
\hline High (5) & 75,00 & $31,38 \%$ \\
\hline Maximum (7) & 150,00 & $62,76 \%$ \\
\hline
\end{tabular}

Affinity range (relative: \%)

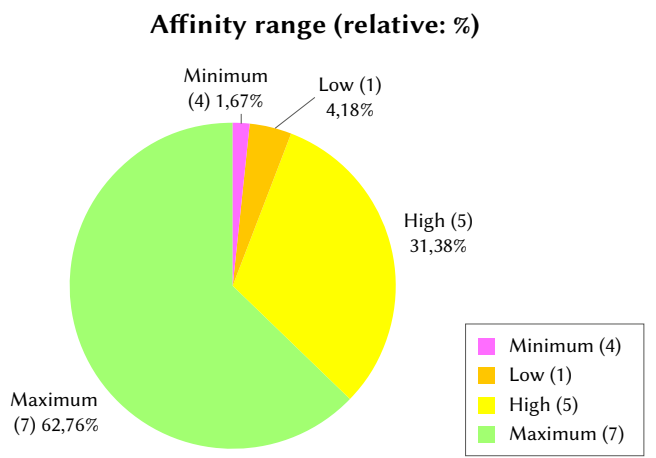


with the definition established by each element used as framework parameters. Therefore, the indicated references reflect, support, and extend the summary identification of each case, which should be understood as a combination of those basic references. In other words, the set of references addresses the basic identification data, which do not respond exclusively to a reference but to the joint definition extracted from all of them.

Also, within the variety of these rituals, the sources and cultures have been diversified to obtain a varied sample that allows a contrast of this thesis's hypothesis with the use of the tool generated from the fieldwork and the systematic literature review. To do this, Grimes's indications [25] about the variety of contexts of the rituals as a basis were followed - group events, intimate/personal, social events, religious, artistic-cultural, sports, political events, etc. For this reason, the cases are grouped by the following contexts, some of which may be mixed or combined - cultural, group, social, political, sports, personal, medical, curative, and religious. A final detailed list of 34 selected cases is presented in Appendix II.

\section{Discussion}

The generic framework was applied to those 34 representative case studies which were obtained by analysing specialised literature that specifically describe the cases in detail; this literature review was not systematic but rather served to broaden the bibliography. A representative sample was chosen which combines the often-linked religious and secular contexts: cultural, group, social, political, sports, personal, medical, curative, and religious. The study chain began with the systematic review, followed by analysing the literature, conducting semi-structured interviews, and designing the evaluation tool; as the final step, the researcher applied the framework to the case studies and obtained the following 14 findings:

1. Rituals exhibit common elements that imply a generic framework of identity. Each ritual adapts based on its type, category, context, and other conditions, but all rituals can be defined by one unique set of parameters.

2. Religious rituals and secular rituals coincide within this defining framework. There are no significant differences regarding identification, design, and implementation; the difference is provided by the context and the meaning given to them by the participants.

3. Ritual identity is intimately linked to the profile of each event, the context in which it is performed, and the participants. Even so, each identity is comparable in both religious and secular rituals, with no significant difference between the two settings.

4. There are ritual elements that themselves define their identity, without a need for a majority of aligned elements. In other words, a ritual can be defined with a few distinct elements, if and when their relative value is significant enough.

5. Conversely, some rituals do not achieve maximum affinity in any element and yet are considered rituals given the average score held by the majority of their elements. This shows that regularity in the elements' affinity produces a result that is just as valid as rituals with only some clearly marked elements.

6. Within the context of the case study sampling where the generic framework was applied, the researcher observed a classification of elements by average affinity. The standard deviation is irrelevant in this set. Three groups were distinguished, from greater to lesser affinity. The first group is made up of meaning and contextualisation, both primaries with an affinity over $75 \%$. The second group holds eight elements (transformation, feeling, music, ceremony, symbolism, need, script, and transcendence) with high affinity. The researcher found the transcendence element, which is traditionally a determinant factor for considering a ritual as such; however, the researcher also found that other elements exhibited an equivalent or distinctly higher affinity, though they are all closely related to the effect that the ritual has on the participant and that the participant affords the ritual. The third and last group contains seven circumstantial and operational elements, with the exception of the impact element, which has a low value in this group but belongs to the second group, by definition. The polysemy element seems residual.

7. The comparison between religious and secular contexts, which coincides with the analysis of the entire set of cases, shows a group of seven elements (meaning, feeling, transformation, need, symbolism, contextualisation, and music) with maximum and high affinities in both contexts. These elements create synergy with the ritual, whether religious or secular, to a greater or lesser degree and homogeneously. Two other elements are placed in the first group, although only in one context each: script in secular and transcendence in religious. All these elements refer to the effect that the ritual has on the participant and vice versa, opposite another large majority of elements that could be considered more circumstantial or operational (e.g. stages, regularity, or ceremony).

8. Transcendence - traditionally assigned as a defining, if not unique, characteristic of a ritual - emerges with high but not maximum significance. It is only in the context of other elements (mentioned in the previous conclusion) that transcendence claims greater prominence but never in isolation.

9. Each element's rating in the two contexts is matched, increasing and decreasing harmoniously, almost in its entirety. Although the religious context provides more defined values, the more established, multitudinous, and vastly recognised profile of the selected religious rituals usually implies greater refinement of the terms and must be considered. The doubles between contexts for each element are balanced and matched in up to eight elements, with a slight percentage difference of about 10 points.

10. A ritual rarely shows affinity in each element. Given the diversity of rituals and their adaptations to local context, participants, culture, and other factors, it is almost impossible that a ritual would need all the elements to be considered as such.

11. Regardless of context, no ritual showed $100 \%$ affinity with all the elements.

12. Ritual affinity depends greatly on the participant and the context. In those cases where affinity borders the threshold between considering a specific event or celebration as a ritual or not (not necessarily established in 50\%), that participant's nature in that context is what significantly defines ritual identity.

13. Rituals can be parameterised and studied following a semiautomatic process that relies on mixed methods, involving qualitative analysis and data analytics.

14. The calibration of the data-analytics generic framework defines identity by assigning the relevance factor. According to how the outside observer gauges that factor when applying the framework, the affinity indexes will vary correspondingly. The presence factor also depends on the outside observer's subjective interpretation. Each element's affinity and total affinity are, therefore, relative to the evaluating individual.

\section{CONCLUSION}

The main hypothesis proposes a similarity between religious and secular rituals and concentrates on comparing the ritual function and the structure of rituals regardless of context. Similarly, the researcher 
designed a data-analytics generic framework that evaluates the degree of ritual affinity of an event or celebration, also independently of that context. The results show that, in effect, religious and secular rituals are defined by a series of common elements that characterise their identity and function and that can be processed through semi-automatic dataanalytics techniques. These elements can be standardised through a data-analytics generic framework and weighted according to the factors' relevance and presence, which can be applied by an outside observer or researcher (or by the interested party themselves) in a possible future evolution of the methodology. To do so, the research shows that this semi-automatic process can be developed as a dataanalytics generic framework in a mixed-methods approach and which combines qualitative and quantitative techniques.

A next step in further studies would be to integrate a third assessment factor into the data-analytics generic framework: priority. This would involve the observer establishing an order to the list of elements of ritual identity, which would require new weighing. Three factors would then be aligned - relevance, presence, and priority. The additional factor of priority provides a more precise measurement if applied correctly, but it also complicates the understanding of the framework as a tool to be applied by an individual, by an active subject of the ritual being analysed, or by an outside observer. Another future step is to implement the data-analytics generic framework as an online tool for open use by any interested party. This step would also offer training and explain in detail how to use the tool. The observer's (researcher's) autonomy would be sought, and the tool would help to optimise the data-analytics generic framework (and the related semiautomatic analysis process) and to provide additional information developed by other researchers, with the aim of sharing and exploring the findings.

\section{APPENDIX I}

ID-1. Sample: Defines the Interviewee's Basic Information

\begin{tabular}{|c|c|c|c|c|}
\hline Unique ID & Category & Code & Question & Response type \\
\hline ID-1-0 & Sample & Primary & Interviewee's unique identifier (anonymized) & Fixed \\
\hline ID-1-0 & Sample & Primary & Date of interview & Fixed \\
\hline ID-1-0 & Sample & Primary & Time of interview & Fixed \\
\hline ID-1-1 & Sample & Primary & Consent & Closed \\
\hline ID-1-2 & Sample & & Interviewee name & Open \\
\hline ID-1-3 & Sample & & Interviewee surname(s) & Open \\
\hline ID-1-4 & Sample & & Interviewee gender & Open \\
\hline ID-1-5 & Sample & & Interviewee email address & Open \\
\hline ID-1-6 & Sample & & Interviewee language & Open \\
\hline ID-1-7 & Sample & & Interviewee city of birth & Open \\
\hline ID-1-8 & Sample & & Interviewee country of birth & Open \\
\hline ID-1-9 & Sample & & Interviewee city of residence & Open \\
\hline ID-1-10 & Sample & & How long has interviewee resided in this city? & Open \\
\hline ID-1-11 & Sample & & Interviewee country of residence & Open \\
\hline ID-1-12 & Sample & & How long has interviewee resided in this country? & Open \\
\hline ID-1-13 & Sample & & Interviewee's age & Open \\
\hline ID-1-14 & Sample & & Interviewee's profession & Open \\
\hline ID-1-15 & Sample & Primary & Interviewee's relation to the study & Open \\
\hline ID-1-16 & Sample & & City where interview takes place & Open \\
\hline ID-1-17 & Sample & & Country where interview takes place & Open \\
\hline ID-1-18 & Sample & & Religion interviewee professes and practices & Mixed \\
\hline
\end{tabular}

ID-2. Scope: Defines the Field of the Ritual

\begin{tabular}{|c|c|c|c|c|}
\hline Unique ID & Category & Code & Question & Response type \\
\hline ID-2-1 & Scope & & To which religion does the ritual pertain? & Mixed \\
\hline ID-2-2 & Scope & & $\begin{array}{c}\text { If not religious, to which other aspect or area does the } \\
\text { ritual pertain? }\end{array}$ & Mixed \\
\hline ID-2-3 & Scope & & $\begin{array}{c}\text { If religious, what is the ritual's relevance within } \\
\text { the religion? }\end{array}$ & Open \\
\hline ID-2-4 & Scope & & $\begin{array}{c}\text { What type of ritual is it, which type of moment } \\
\text { does it express? }\end{array}$ & Mixed \\
\hline
\end{tabular}

ID-3. Characterisation: Identifies the Ritual

\begin{tabular}{|c|l|l|c|c|}
\hline Unique ID & Category & Code & Question & Response type \\
\hline ID-3-1 & Characterization & & $\begin{array}{c}\text { How many people normally participate in } \\
\text { the ritual? }\end{array}$ & Closed \\
\hline ID-3-2 & Characterization & & How long has the ritual been celebrated? & Closed \\
\hline ID-3-3 & Characterization & & How frequently is the ritual celebrated? & Closed \\
\hline ID-3-4 & Characterization & Primary & What is the protocol of the ritual? & Open \\
\hline ID-3-5 & Characterization & Primary & What are the steps or stages of the ritual? & Open \\
\hline ID-3-6 & Characterization & & Is dance used at any time? & Open \\
\hline ID-3-7 & Characterization & & $\begin{array}{c}\text { What official or unofficial training is } \\
\text { required of the officiant/minister? }\end{array}$ & Open \\
\hline ID-3-8 & Characterization & & $\begin{array}{c}\text { What prior experience is required of the } \\
\text { officiant/minister? }\end{array}$ & Open \\
\hline ID-3-9 & Characterization & & $\begin{array}{c}\text { What prior experience is required of the } \\
\text { participant? }\end{array}$ & Open \\
\hline ID-3-10 & Characterization & & $\begin{array}{c}\text { What preparations does the ritual require of } \\
\text { the officiant/minister? }\end{array}$ & Open \\
\hline ID-3-11 & Characterization & & $\begin{array}{c}\text { What preparations does the ritual require of } \\
\text { the participant? }\end{array}$ & Open \\
\hline
\end{tabular}

ID-4. Meaning: Explains the Meaning of the Ritual according to the Interviewee

\begin{tabular}{|c|c|c|c|c|}
\hline Unique ID & Category & Code & Question & Response type \\
\hline ID-4-1 & Meaning & Primary & What symbology is used? & Open \\
\hline ID-4-2 & Meaning & Primary & Which tools or objects are used and how? & Open \\
\hline ID-4-3 & Meaning & Primary & $\begin{array}{c}\text { What is the culminating point of the ritual and } \\
\text { what does it mean? }\end{array}$ & Open \\
\hline ID-4-4 & Meaning & Primary & What does each step or stage mean? & Open \\
\hline ID-4-5 & Meaning & & What significance is portrayed by the dances used? & Open \\
\hline ID-4-6 & Meaning & & What is the significance of the texts used? & Open \\
\hline
\end{tabular}

ID-5. Behaviour: Describes the Behaviour of the Ritual Participants

\begin{tabular}{|c|c|c|c|c|}
\hline Unique ID & Category & Code & Question & Response type \\
\hline ID-5-1 & Behaviour & Primary & What behaviour do the participants exhibit? & Open \\
\hline ID-5-2 & Behaviour & Primary & $\begin{array}{c}\text { What interaction is there between participants in } \\
\text { the ritual? }\end{array}$ & Open \\
\hline ID-5-3 & Behaviour & & $\begin{array}{c}\text { What is the behaviour of the officiant/minister } \\
\text { during the ritual? }\end{array}$ & Open \\
\hline ID-5-4 & Behaviour & & $\begin{array}{c}\text { What is the behaviour of the officiant/minister } \\
\text { before and after the ritual? }\end{array}$ & Open \\
\hline
\end{tabular}

ID-6. Transference: Indicates the Ritual's Relationship to External Elements

\begin{tabular}{|c|c|c|c|c|}
\hline Unique ID & Category & Code & Question & Response type \\
\hline ID-6-1 & Transference & & $\begin{array}{l}\text { Is there an identification of the ritual with any } \\
\text { specific person? }\end{array}$ & Open \\
\hline ID-6-2 & Transference & Primary & $\begin{array}{l}\text { Is there an identification of the ritual with any } \\
\text { other external aspects? }\end{array}$ & Open \\
\hline ID-6-3 & Transference & Primary & $\begin{array}{l}\text { What influence or overlapping with other rituals } \\
\text { does this ritual exhibit? }\end{array}$ & Open \\
\hline ID-6-4 & Transference & Primary & $\begin{array}{c}\text { What influence or overlapping with other rituals } \\
\text { does this ritual have? }\end{array}$ & Open \\
\hline ID-6-5 & Transference & & $\begin{array}{c}\text { What influence does this ritual have from abroad } \\
\text { or from other cultures? }\end{array}$ & Open \\
\hline ID-6-6 & Transference & & $\begin{array}{l}\text { What influence does this ritual have abroad or in } \\
\text { other cultures? }\end{array}$ & Open \\
\hline ID-6-7 & Transference & Primary & $\begin{array}{l}\text { Is there any transference from Society to the } \\
\text { ritual? }\end{array}$ & Open \\
\hline ID-6-8 & Transference & Primary & $\begin{array}{l}\text { Is there any transference from the ritual to } \\
\text { Society? }\end{array}$ & Open \\
\hline
\end{tabular}

ID-7. Evolution: Explains the Ritual's Historic Evolution

\begin{tabular}{|c|l|c|c|c|}
\hline Unique ID & Category & Code & Question & Response type \\
\hline ID-7-1 & Evolution & & $\begin{array}{c}\text { How has the officiant's/minister's profile evolved } \\
\text { throughout the ritual's history? }\end{array}$ & Open \\
\hline ID-7-2 & Evolution & & $\begin{array}{c}\text { How has the participant's profile evolved } \\
\text { throughout the ritual's history? }\end{array}$ & Open \\
\hline ID-7-3 & Evolution & & $\begin{array}{c}\text { What modifications do you expect the ritual to } \\
\text { undergo in the near future? }\end{array}$ & Open \\
\hline ID-7-4 & Evolution & & $\begin{array}{c}\text { What modifications has the ritual undergone since } \\
\text { its creation? }\end{array}$ & Open \\
\hline ID-7-5 & Evolution & & What variations of the ritual are there and where? & Open \\
\hline
\end{tabular}


ID-8. Impact: Describes the Ritual's Relationship with Media and Society in General

\begin{tabular}{|c|c|c|c|c|}
\hline Unique ID & Category & Code & Question & Response type \\
\hline ID-8-1 & Impact & Primary & How is the ritual attacked, by whom, and why? & Open \\
\hline ID-8-2 & Impact & & What type of coverage does it receive in the media? & Open \\
\hline ID-8-3 & Impact & & What type of coverage does it receive in social media? & Open \\
\hline ID-8-4 & Impact & & Link to further information on the ritual & Open \\
\hline
\end{tabular}

ID-9. Music: Describes the Role of Music in the Ritual and Its Relationship with the Other Categories

\begin{tabular}{|c|c|c|c|c|}
\hline Unique ID & Category & Code & Question & Response type \\
\hline ID-9-1 & Music & Primary & What music is used? & Open \\
\hline ID-9-2 & Music & & What musical style(s) accompany the ritual? & Open \\
\hline ID-9-3 & Music & & How frequently is music used? & Open \\
\hline ID-9-4 & Music & & $\begin{array}{c}\text { Which specific moments use music, and what type } \\
\text { of concrete music? }\end{array}$ & Open \\
\hline ID-9-5 & Music & Primary & $\begin{array}{c}\text { Which people are involved musically: participants, } \\
\text { minister, separate group, etc. }\end{array}$ & Open \\
\hline ID-9-6 & Music & & What musical instruments are used? & Open \\
\hline ID-9-7 & Music & & If there are lyrics, in what language are they used? & Open \\
\hline ID-9-9 & Music & & If there are lyrics, who sings them and when? & Open \\
\hline ID-9-10 & Music & & $\begin{array}{c}\text { If there is dancing associated with the music, what } \\
\text { type of dancing is it? }\end{array}$ & Open \\
\hline ID-9-11 & Music & Primary & What does the music mean when used within the \\
context? & Open \\
\hline ID-9-12 & Music & & What symbology is directly associated with the \\
ritual's music? & Open \\
\hline
\end{tabular}

\section{Appendix II}

Selected Case Studies

\begin{tabular}{|c|c|c|}
\hline Case ID & Context & Ritual contrasted with generic framework \\
\hline 1 & Cultural & Artist's preparation before a performance \\
\hline 2 & Cultural & Musical performance \\
\hline 3 & Cultural, Religious & Dressing a bullfighter with a 'traje de luces' \\
\hline 4 & Group & Initiation into a gang ('mara') \\
\hline 5 & Group & Group breakfast/lunch/dinner \\
\hline 6 & Group & Tea ceremony \\
\hline 7 & Group & $\begin{array}{l}\text { Non-religious initiation (i.e. into a sect, army, society, } \\
\text { fraternity, etc.) }\end{array}$ \\
\hline 8 & Group & $\begin{array}{c}\text { Use of recreational drugs (wine, alcohol, coffee, tobacco, } \\
\text { marijuana) in a group }\end{array}$ \\
\hline 9 & Group & Modern hunting in a group \\
\hline 10 & Social, Political & Ritual of taking office as president of a nation \\
\hline 11 & Social, Political & Participating in democratic elections of India in Europe \\
\hline 12 & Social, Cultural & All Souls' Day, Day of the Dead \\
\hline 13 & Social & Crop harvest, grape harvest, olive harvest \\
\hline 14 & Social & Releasing sky (or Chinese) lanterns \\
\hline 15 & Social & New Year's Eve and New Year (countdown) \\
\hline 16 & Social & Female puberty ritual \\
\hline 17 & Social, Religious & Carnival: Burial of the Sardine \\
\hline 18 & Social, Religious & Welcoming the arrival of spring, changing of the seasons \\
\hline 19 & Sports & Running (jogging) \\
\hline 20 & Sports & Elite athlete's preparation prior to competition \\
\hline 21 & Sports & Practicing yoga \\
\hline 22 & Sports, Group & Attendance at mass sports events (e.g. football) \\
\hline 23 & Personal & Preparing and enjoying coffee \\
\hline 24 & Medical, Curative & Placebo and assistance rites in medicine \\
\hline 25 & Medical, Curative & Ritual healing \\
\hline 26 & Religious, Curative & Shamanic rites \\
\hline 27 & Religious & Mha Pujā in Nepal \\
\hline 28 & Religious & Catholic confirmation \\
\hline 29 & Religious & Religious initiation \\
\hline 30 & Religious & Religious offering (floral, ornamental, etc.) \\
\hline 31 & Religious & Jewish Passover \\
\hline 32 & Religious & Burning incense, lighting a candle \\
\hline 33 & Religious & Breaking the fast at the end of Ramadan (Eid al-Fitr) \\
\hline 34 & Religious, Personal & Hindu sun salutation \\
\hline
\end{tabular}

ACKNOWLEDGMent

Special thanks go to Prof Lluís Oviedo from the Pontifical Antonianum University (Rome, Italy) as $\mathrm{PhD}$ supervisor, who supported the research process all the way, and to Prof Bernardo Pérez as $\mathrm{PhD}$ programme director from the Theological Institute of Murcia at Universidad de Murcia (Spain), who encouraged me throughout the process. The author also thanks all the host universities, libraries, and interviewees that sympathised with this research.

\section{REFERENCES}

[1] E. Haynes, R. Garside, J. Green, M.P. Kelly, J. Thomas, C. Guell, "Semiautomated text analytics for qualitative data synthesis", Research Synthesis Methods, vol. 10, no. 3, pp. 452-464, 2019.

[2] A. J. Johs, D.E. Agosto, R.O. Weber, "Oualitative investigation in explainable artificial intelligence: A bit more insight from social science". arXiv preprint arXiv:2011.07130, 2020.

[3] G. Abeza, N. O’Reilly, M. Dottori, B. Séguin, O. Nzindukiyimana, "Mixed methods research in sport marketing", International fournal of Multiple Research Approaches, vol. 9, no. 1, pp. 40-56, 2015.

[4] J. W. Creswell, V.L.P. Clark, "Designing and conducting mixed methods research", Sage Publications, 2017.

[5] R. B. Johnson, A.J. Onwuegbuzie, "Mixed methods research: A research paradigm whose time has come", Educational Researcher, vol. 33, no. 7, pp. 14-26, 2014.

[6] P. Leavy, "Research design: Quantitative, qualitative, mixed methods, artsbased, and community-based participatory research approaches", Guilford Publications, 2017.

[7] R. Wille, "Conceptual landscapes of knowledge: A pragmatic paradigm for knowledge processing", in Classification in the Information Age, pp. 344-356, Berlin, Heidelberg: Springer, 1999.

[8] R. Wille, "Methods of conceptual knowledge processing", in Formal Concept Analysis, pp. 1-29, Berlin, Heidelberg: Springer, 2006.

[9] K. F. Punch, "Introduction to social research: Quantitative and qualitative approaches", Sage: London, 1998.

[10] A. Tashakkori, C. Teddlie (Eds.), "Sage handbook of mixed methods in social \& behavioral research", Sage Publications:Thousand Oaks, CA, 2010.

[11] P. Bazeley, "Issues in mixing qualitative and quantitative approaches to research", in Applying Qualitative Methods to Marketing Management Research, pp. 141, 156, 2004.

[12] C. R. Kothari, "Research methodology: Methods and techniques", New Age International, 2004.

[13] R. Kumar, R. "Research methodology: A step-by-step guide for beginners", Sage Publications Limited:Thousand Oaks, CA, 2019.

[14] S. Kumar, P. Phrommathed, P. "Research methodology", Springer, pp. 43-50, 2005.

[15] G. Rodríguez Gómez, J. Gil Flores, E. García Jiménez, “Metodología de la investigación cualitativa”, Aljibe: Málaga, 1999.

[16] N. Astrakhantsev, D. Turdakov, N. Vassilieva, "Semi-automatic data extraction from tables", in RCDL, pp. 14-20, 2013.

[17] A. Jaimes, J.R. Smith, "Semi-automatic, data-driven construction of multimedia ontologies", in 2003 International Conference on Multimedia and Expo ICME '03 Proceedings (Cat. No. 03TH8698), Vol. 1, pp. I-781, IEEE, 2013

[18] R. Newell, P. Burnard, "Research for evidence-based practice", Blackwell Publishing, 2006.

[19] G. V. Glass, "Primary, secondary, and meta-analysis of research", Educational Researcher, vol. 5, no. 10, pp. 3-8, 1976.

[20] M. Hunt, M. "How science takes stock: The story of meta-analysis", Russell Sage Foundation, 1997.

[21] J. L. Barrett, J. L. "Cognitive science, religion and theology: From human minds to divine minds", Templeton Press: West Conshohocken, PA, 2011.

[22] C. Bell, "Ritual theory, ritual practice", Oxford University Press, 1992.

[23] T. F. Driver "Liberating rites: Understanding the transformative power of ritual", BookSurge Publishing, 2006.

[24] M. Eliade,"The sacred and the profane: The nature of religion", Harvest,1957.

[25] R. L. Grimes, “The craft of ritual studies”, Oxford University Press, 2014. 
[26] B. Malley, J. Barrett, "Can ritual form be predicted from religious belief? A test of the Lawson-McCauley hypotheses", fournal of Ritual Studies, pp. 1-14, 2003.

[27] O. Zell-Ravenheart, M.G. Zell-Ravenheart, "Creating circles and ceremonies", Red Wheel/Weiser, 2006.

[28] V. W. Turner, "The forest of symbols: Aspects of Ndembu ritual", (Vol. 101). Cornell University Press, 1967.

[29] A. Van Gennep, "The rites of passage", University of Chicago Press, 2011.

[30] A. Warburg, W.F. Mainland, W. F. "A lecture on serpent ritual", fournal of the Warburg Institute, vol. 2, no. 4, pp. 277-292, 1939.

[31] J. D. Kelly, M. Kaplan, "History, structure, and ritual", Annual Review of Anthropology, vol. 19, no. 1, pp. 119-150, 1990.

[32] R. N. McCauley, E.T. Lawson, "Bringing ritual to mind", in Ecological approaches to cognition: Essays in honor of Ulric Neisser, pp. 285-312, Psychology Press, 1999.

[33] F. Staal, "The meaninglessness of ritual", Numen, vol. 26, no. 1, pp. 2-22, 1979.

[34] S. E. Fredericks, "Environmental Guilt and Shame: Signals of Individual and Collective Responsibility and the Need for Ritual Responses", Oxford University Press, 2001.

[35] P. Freston, "Evangelicals and Politics in Asia, Africa and Latin America", Cambridge University Press: New York, 2001.

[36] E. R. Leach, "G. Ritualization in man: Ritualization in man in relation to conceptual and social development", Philosophical Transactions of the Royal Society of London. Series B, Biological Sciences, vol. 251, no. 772, pp. 403-408, 1966.

[37] M. A. Duncan, "Duncan's Ritual of Freemasonry", Courier Corporation, 2007.

[38] I. Strenski, "What's rite? Evolution, exchange and the big picture", Religion, vol. 21, no. 3, pp. 219-225, 1991.

[39] N. C. Chen, M. Drouhard, R. Kocielnik, J. Suh, C.R. Aragon, "Using machine learning to support qualitative coding in social science: Shifting the focus to ambiguity., ACM Transactions on Interactive Intelligent Systems (TiiS), vol. 8, no. 2, pp. 1-20, 1998.

[40] R. Likert, "A technique for the measurement of attitudes", Archives of Psychology, 1932.

[41] A. Joshi, S. Kale, S. Chandel, D.K. Pal, "Likert scale: Explored and explained”, British fournal of Applied Science \& Technology, vol. 7, no. 4, pp. 396-403, 2015.

[42] M. Deutsch, L. Solomon, "Reactions to evaluations by others as influenced by self-evaluations", Sociometry, vol. 22, no. 2, pp. 93-112, 1959.

[43] P. Skolnick, "Reactions to personal evaluations: A failure to replicate", Journal of Personality and Social Psychology, vol. 18, no. 1, pp. 62-67, 1971, doi: 10.1037/h0030709 1971.

[44] S. E. Taylor, E. Neter, H.A. Wayment, "Self-evaluation processes", Personality and Social Psychology Bulletin, vol. 21, no. 12, pp. 1278-1287, 1995.

[45] M. Conley-Tyler, "A fundamental choice: Internal or external evaluation?", Evaluation fournal of Australasia, vol. 4, no. 1-2, pp. 3-11, 2005.

[46] H. Yang, J. Shen, "When is an external evaluator no longer external? Reflections on some ethical issues", American fournal of Evaluation, vol. 27, no. 3, pp. 378-382, 2006.

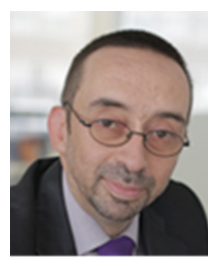

\section{Prof. Dr. Daniel Burgos}

He works as Vice-rector for International Research (http:// research.unir.net), UNESCO Chair on eLearning and ICDE Chair in OER (http://research.unir.net/unesco) at Universidad Internacional de La Rioja (UNIR, http://www. unir.net). He is also Director of the Research Institute for Innovation \& Technology in Education (UNIR iTED, http:// ited.unir.net). He has contributed to +60 research projects focused on Educational Technology and Innovation, Learning Analytics, Open Education, Social entrepreneurship, eGames, Competence development, and other topics, funded by the European Commission and other institutions. $\mathrm{He}$ has published over 180 scientific papers, 20 books and 20 special issues. He has been the jury chair of the 2016 and 2018 UNESCO Prize for the Use of ICTs in Education. He holds degrees in Communication $(\mathrm{PhD})$, Computer Science (Dr. Ing), Education $(\mathrm{PhD})$, Anthropology $(\mathrm{PhD})$, Business Administration (DBA), Theology (PhD), Management (PhD), Open Science \& STEM (PhD) and Artificial Intelligence (Postgraduate, MIT). 